\title{
Tooth Part
}

National Cancer Institute

\section{Source}

National Cancer Institute. Tooth Part. NCI Thesaurus. Code C74952.

Any part of a tooth. 